\title{
EMOTIONS IN HOLOCAUST EDUCATION - THE NARRATIVE OF A HISTORY TEACHER
}

\author{
DOI: http://dx.doi.org/10.17159/2223-0386/2019/n21a3 \\ Brenda Gouws \\ University of Cape Town \\ bgouws@iafrica.com
}

\begin{abstract}
Emotion is an integral part of Holocaust education and inculcating empathy in learners is a well-used pedagogical tool to encourage learners to connect with the victims. This is necessary because of the vast number of victims who died at the hands of the Nazis and their collaborators six million Jews and five million non-Jews. These numbers are generally difficult to comprehend and there can be a tendency to crush thoughts of all the victims together into a single unit, say, the six million, rather than embrace the thought of six million individuals. To help learners relate better to the Jewish victims and survivors, the personal stories of individuals are often told to personalise the Holocaust. This is a tool used in both schools and museums by history teachers and museum educators.
\end{abstract}

Teaching the Holocaust is not a dispassionate, disconnected experience for history teachers. They are often personally affected whether to a greater or lesser degree, and both their teaching and understanding of the Holocaust are often linked to their personal stories. This article is based on the story of one history teacher, whose personal story shaped her Holocaust pedagogy and philosophy when she taught about the Holocaust. The Holocaust is included in the national history curriculum for Grade 9 and 11 learners in the South African school curriculum. Within a qualitative, narrative inquiry framework, the article discusses the personal story of Florence, a Coloured South African history teacher. Along with her family, she did not personally experience apartheid trauma, as many other current South African history teachers did, nor did her family have any personal connections to World War II Europe. Florence simply drew on her personal experiences as a young girl growing up in a lower middle-class family to formulate her own pedagogy with which to teach the Holocaust and engender empathy in her learners. She did this by including techniques such as visualisations to create a certain mood in the classroom before embarking on teaching what, to her, was a horrific, evil event, and to ensure that the learners did not take what they were going to hear lightly. Her methodology was devised to inculcate empathy and enhance depth of understanding.

Kevwords: Empathy; Holocaust Education; History Teachers; Narrative Inquiry; Personal Stories; South Africa. 


\section{Introduction}

Teaching the Holocaust is a complex matter. The topic is fraught with controversy and challenges, be they personal or professional, social or historical, emotional, psychological, philosophical or educational. It can generate heated debate, stir up emotion and even leave teachers perplexed, so it offers a challenge even for "gifted and experienced teachers" (Waterson, 2009:1). Teaching the Holocaust in South Africa means that apart from teaching historical content, educators are thrust into a minefield of discussions about difficult and emotionally-laden issues like genocide, torture, political killings, propaganda, racism, antisemitism, Israel, and apartheid in a country where the recent past casts a long, dark shadow over the present. Less problematic subjects also exist, but sometimes these pose questions that are almost as complex, so, unavoidably, engagement with the Holocaust means dealing with the emotions of both teachers and learners.

This article explores how one Coloured ${ }^{1}$ history teacher's personal story that was rooted in South Africa's discriminatory past shaped her history ${ }^{2}$ education pedagogy and Holocaust education philosophy. It is the story of someone teaching the Holocaust, not an in-depth study of Holocaust education in a context where the Holocaust is deeply embedded in the national consciousness as it is in Europe.

As a child, Florence ${ }^{3}$ grew up in apartheid South Africa where race was a feature of the socio-political landscape, as it was in Nazi Germany. She later experienced South Africa's historic transition from apartheid to democracy and now teaches history in a local government high school. In telling her story, Florence drew both knowingly and unknowingly, not only on her pedagogical historical knowledge, but also on her life experiences, her feelings, memories and her personal philosophy that people should treat others well (Gouws, 2018a). For Florence, the Holocaust was a history to

1 Race is an imposed social construct that arose in the late $19^{\text {th }}$ and early $20^{\text {th }}$ centuries out of a false application of Darwinian theories of natural selection. From colonial times, Coloureds were believed to be the descendants of slaves and the result of mixed-race unions. Under apartheid they were ascribed minimally greater status than Blacks but were nonetheless oppressed and marginalised. During her interview, Florence referred to herself as Coloured and was comfortable with the term. Therefore, for practical purposes, this article will continue to use the term Coloured to reflect her lived experience.

2 In this article I make a distinction between history and History, history being everything that happened in the past and History being the academic field of study that teaches about the past and legacies of the past in the present (Corfield, 2008, p. 1)

3 The name Florence is a pseudonym, used to protect the participant's identity, "privacy and dignity" (Josselson, 2007, p. 537) as ethically required in qualitative research. 
which she had no direct personal connection, nor was the topic any more important to her than any other topic that she was required to teach as part of the national history curriculum. Making sense of it in the context of her reality meant finding points of connection with her personal story in order to teach it to the best of her ability.

\section{The concept of race in Nazi Germany and South Africa}

The concept of a racial hierarchy both in apartheid South Africa and in Nazi Germany was one of the pillars on which the two regimes were built. Both implemented dehumanisation strategies based on the notion of a lesser "other", thereby targeting them for discrimination, stereotyping, terror, violence, torture and ultimately murder. In Nazi Germany, the Jews were considered sub-human, and were placed on the lowestrung of the "race ladder." Such dehumanisation is, in fact, one of the interrelated processes deemed necessary for the loosening of moral restraints that leads to the perpetration of sanctioned violence against those considered to be lesser human beings, and which exists within policies of sanctioned genocide (Kelman, 1973:48). Under Nazi domination, the Jews were not the only group to be considered racially inferior. Other victim groups included the Roma and Sinti, black Germans, and Eastern Europeans, who were designated "untermenschen". ${ }^{4}$ Germans who resulted from unions between Africans and Germans were labelled "Rhineland Bastards" and persecuted, while millions of Russians, Jehovah's Witnesses, political prisoners and even the German disabled were interned in concentration camps or other facilities and eventually murdered, starved or worked to death.

The National Party government came to power in South Africa in 1948, after which racial profiling was instituted. The concept of different races was a creation of apartheid ideology under which South Africans were categorised, based on their skin colour, as Coloured, White, Indian, or Black. Apartheid legislation called for separate development of the different race groups, which resulted in segregation of people and implementation of economic policies that aimed to enrich one group, Whites, while disadvantaging the rest. For Coloureds, this meant that they were forced to use separate amenities, attend Coloured schools and live in Coloured areas, close to the factories where they were expected to work. Yet, despite our knowledge that race is a pseudoscientific social construct, the use of racial categorisation persists and the outdated colonial structure is still

4 "Untermenschen" or "under-people" were considered racially or socially inferior. 
considered to be "the natural order of things" by some (Debut, 2019:np; Pillay, 2019:4), even though there is no scientific or biological basis for racial categorisation and scientific research has long since discredited and invalidated the concept of race. As a result, the legacy of apartheid racism lingers in the feelings of many in the Coloured community and Florence, who was classified at birth as Coloured, continues to be classified as such today.

\section{The Holocaust in the History curriculum}

It has been proposed that there are two aims of teaching history, intrinsic and extrinsic (Slater, 1995). The former is inherent in the subject discipline, where the primary rationale for teaching history, including the Holocaust, is to inculcate historical knowledge in the learners. To achieve this objective, history teachers conduct their research using primary and secondary sources, following the guidelines of the History curriculum. The extrinsic aim of teaching history has a social function, that is, to bring about societal change (McCully, 2012).

These two aims of history are integrated into History education in South Africa, which is based on the Constitution of South Africa. The extrinsic aim is written into one of the objectives of the Preamble is to "heal the divisions of the past and establish a society based on democratic values, social justice and fundamental human rights" (Department of Basic Education (DoBE), 2011b:3) and is echoed in the latest national History curriculum document, the Curriculum Assessment and Policy Statement (CAPS). The CAPS curriculum encourages history teachers to educate about democracy, support citizenship in a democracy by explaining and encouraging the values of the South African Constitution, promote human rights, and challenge prejudice by discussing issues of race, class, gender, ethnicity and xenophobia (DoBE, 2011b). The history teachers strive to bring about this social transformation by embracing the qualities of "compassion, critical thinking, ubuntu and personal integrity" (Cushman, 2016: 100). One of the tools they use is endorsed by the Department of Basic Education, namely empathy, which is defined as "the ability to understand another person's actions, ideas or feelings" (DoBE, 2017; Department of Education, 2002:106). A deeply emotive dimension is therefore woven into this human rights-based curriculum while a golden thread of agency runs through the fabric of history education in South Africa. 
There have been many incarnations of the national History curriculum in South Africa's recent past, each with its own focus. The first post-apartheid curriculum was the National Curriculum Statement (NCS), which embraced a constructivist, outcomes-based approach. Learners were encouraged to make sound judgements not only based on the historical past, but also on the present and for the future; empathy and questions of choice and identity were part of this discourse.

The topic of the Holocaust was introduced into this ambitious NCS in support of its aims in 2007 because of its synergy with the aims and purpose of the then new History curriculum. The study of the Holocaust has long been regarded as a "moral instrument" with which "to heal the injustices and divisions of the past" (Morgan, 2015:370) and the apartheid laws introduced into South Africa in 1948, echoed Nazi Germany's racist policies of 1933. This meant that many parallels could be drawn between the enactment of the ideologically similar laws of these two countries in order to inform the present. ${ }^{5}$ It was also believed by the proponents of Holocaust education, Gail Weldon of the Western Cape Education Department and Marlene Silbert of the Cape Town Holocaust and Genocide Centre, that education about other difficult histories, that is the Holocaust, could ease the path to difficult discussions about apartheid. In South Africa, the Holocaust is taught to all Grade 9 learners as well as to Grade 11 learners who choose History as a matriculation elective.

In contrast to the constructivist outcomes-based NCS-History curriculum of 2002, the latest CAPS-History curriculum is objectivist and contentfocused (DoBE, 2011b). However, despite the linear, fact-based orientation of this curriculum, teaching the Holocaust still means teaching the emotive topics of genocide, racism and violations of human rights, as these are integral to Holocaust education. The focus of the CAPS document might be less socially driven than that of the NCS, but emotion remains an element of both.

5 The parallel nature of apartheid South Africa and Nazi Germany exists only between 1933 and 1938. During that time, people in both countries were racially identified and marked. In Nazi Germany, Jews were forced to wear yellow stars and in South Africa, Blacks were required to carry passbooks. In both countries too, it was legislated by the State that people were to live in separate, allocated spaces (ghettos or homelands). Jobs were reserved for the elite groups and legal restrictions were placed on marriage. Separate amenities were enforced as were separate schools. In both instances, the State Police were used as instruments of fear relying on detentions, violence, and torture to instil terror. These racist governments intended to dehumanise, separate, sow suspicion and increase hostilities amongst people. However, after 1938 the parallels are no longer applicable, as the Nazis began to engage in state-sponsored murder, an act that was never sanctioned by the South African government. 
But curriculum changes are once again afoot and a Ministerial Task Team (MTT) was recently appointed to assess the place of history in the curriculum. In their report they concluded that the History curriculum should develop a "sympathetic understanding for humanity and the human condition - including the promotion of human solidarity irrespective of gender, race, ethnicity, colour or creed" (DoBE, 2018:43), once again emphasising the social function of history. They noted that historical skills marked for inclusion were the ability to show empathy by "walking in someone else's shoes" (DoBE, 2011a:9) and to be able to view historical events from more than one perspective (DoBE, 2018). Thus, the History curriculum is once again earmarked as a vehicle for social transformation and is yet again reliant on the agency of history teachers. Whether this social focus will remain as part of the aims of the new History curriculum or are included in the topics as it was in the NCS is yet to be discovered.

Who the history teachers are, and what they think and feel is therefore clearly important. To be able to perform these tasks, history teachers need to possess diverse skills. They need to be subject specialists as well as being able to cope with controversial issues that arise, and to manage their own as well as their learners' emotions. In addition, teaching the Holocaust "involves unique demands, pressures, and potential pitfalls" (Lindquist, 2007:21-22). This is an added complexity for South African history teachers due to the parallel nature of the two histories of apartheid South Africa and Nazi Germany during the period 1933 to 1938.

\section{Emotion in Holocaust education}

According to Hargreaves (1998:835), emotions lie "at the heart of teaching," and are fundamental to teaching and learning (Becker, Goetz, Morger, \& Ranellucci, 2014: 16; Hargreaves, 1998:835). An understanding of the nature of emotions within the school context is therefore essential (Gaines et al., 2019). This is especially true in divided societies where "history is closely tied to the emotions associated with national identity and collective belonging" (McCully, 2012:148) and where complex topics, like racism, apartheid, colonialism, human rights and equality are embedded in the History curriculum (Wassermann \& Bentrovato, 2018). As a result, when teaching the Holocaust, history teachers are challenged to confront not only the emotive nature of these topics but also to explore their own beliefs and attitudes (Freedman, 2015). Complicating matters further, this emotive component of history education is contested, with 
some researchers arguing that history is a cognitive process about historical inquiry and not an emotive one, and as such, feelings and imagination should not be a part of history teaching (Slater, 1995). Teaching history in a divided society also creates special challenges. Here, the shadow of apartheid always looms, and this is certainly true when teaching about the Holocaust, particularly as both topics are taught in the Grade 9 year (DoBE, 2011b).

Having only recently emerged from our recent past of mass conflict, colonialism and apartheid, many South Africans continue to suffer these effects personally and the emotional impact is undeniable. History teachers who experienced violence and trauma still hurt, and many educators have not yet had an opportunity to deal with their own suffering (Nates, 2010). Complicating matters, the current political climate in South Africa is tension-filled as, despite the adoption of an all-inclusive democracy that embraces ubuntu, people remain suspicious of each other and old hatreds persist. Within this framework, history teachers find themselves addressing issues of stereotyping, xenophobia, racism and prejudice as part of the CAPS curriculum and topics of exclusion, marginalisation of minor groupings and polarisation creep into classroom discourse.

In addition to the current socio-political climate, history teachers' personal feelings and attitudes to World War II (WWII) differ vastly. At the time of WWII and up to the present, the role played by South Africa was deeply divisive. Afrikaners at that time, for instance, could not fathom how South Africa could join the Allies, while many South Africans, including Jews, fought against Germany, both at the Front and behind the scenes. Even today, there are vastly differing views on WWII depending on the lens through which it was viewed and echoes of who believed what lingers. Ultimately, in the classroom each history teacher brings her personal views on this history to her teaching of the Holocaust. For some, the geographical, social and political distance from Europe of the 1930s and 1940s, means that they have little physical, emotional or geographical connection to WWII Europe. For these history teachers, there might be a limited interest in, apathy about, or even an aversion to European history. In addition, because many are still trying to make sense of their own contested past, the study of the fate of the Jews during the Holocaust could seem irrelevant (Avraham, 2010). In contrast, for others there is a very deep connection to WWII, be it through family or circumstance. As a result, the teaching of WWII and the Holocaust is greeted with mixed feelings. However, 
whatever their feelings on the role of South Africa and the political ramifications of WWII history on South Africa, the history teachers have differing responses to the teaching of it. Florence, for instance, enjoyed teaching world history, which she believed was a change from teaching about South Africa. According to her, teaching about South Africa and apartheid had become "boring" because it was taught so often across the different grades (Gouws, 2018a).

Teaching the Holocaust as a component of WWII history brings its own challenges, one of which is that teaching the Holocaust is emotional (Moisan, Hirsch, \& Audet, 2015). It is seldom undertaken in a dispassionate, clinical manner as both history teachers and learners are bombarded with powerful, complex responses to the issues that arise. For some teachers teaching the Holocaust is viewed enthusiastically and they describe it as "thought-provoking", "interesting", "moving on a humanitarian level" or as an opportunity to "enlighten and support the learners". For others, however, teaching the Holocaust is "difficult" and "emotional" (Weldon, 2005:6). History teachers have described the Holocaust as "baffling", "disturbing", "horrible", "painful", and even as "a torment" (Gouws, 2018b:301). Such feelings are not unique to South African history teachers because in other countries too, such as Canada and the United Kingdom, teachers also find teaching the Holocaust daunting (Moisan et al., 2015; Pettigrew et al., 2009).

There are various reasons for these feelings. In South Africa, the difficulties of teaching the Holocaust are compounded when the lessons are peppered with apartheid discourse, even as they try to avoid "ripping open the wounds of racism" (Chikoko, Gilmour, Harber, \& Serf, 2011:1314). As mentioned earlier, some history teachers continue to carry the baggage of their apartheid pasts (Tibbitts, 2006; Weldon, 2005; 2008) and find themselves unable to divorce their own history from what they are teaching (Nates, 2011). But, in our fractured society, issues of racism and apartheid are unavoidable. As a result, teaching the Holocaust means being confronted not only with the traumatic nature of the Holocaust, but also with familiar overlapping themes that prod distressing personal memories (Tibbitts, 2006) and force the history teachers to confront those pasts as either as victims or perpetrators (Wassermann, 2011). Faced with uncomfortable, overwhelming feelings sometimes history teachers simply avoid them and do not teach the offending topics (Bromley \& Russell, 2010; Chikoko et al., 2011; Van Driel, 2003). In fact, on occasion History 
is dropped, as in the case of a school where one year the learners decided that History should not be in the curriculum, so in that year History was not taught and they studied accounting instead (Gouws, 2018a).

With these myriad emotions crowding an emotional educational space, empathy is regarded as a sought-after skill, because it enables history teachers and learners to explore the past with compassion. By developing empathy, learners are encouraged to understand the situation of people in the past: their state of mind, the significance of the situations in which they found themselves, their values and beliefs, and the feelings that they must have experienced. This is achieved by drawing on their imaginations, and making inferences about how others might feel given certain facts that are not necessarily based on fact or knowledge but on "personal experiences, social relations, and everyday life" (Harris, Foreman-Peck, \& Northants, 2004:99; Morgan, 2015:374). Many history teachers use this technique to negotiate a path through the emotional minefield of the Holocaust, to gain insight into the thoughts and feelings of victims, perpetrators, bystanders and rescuers, and to better understand how and why the Holocaust happened. Methodologically, this is sometimes done through role-play or visualisations. However, the idea of asking learners to draw connections between their experiences in the present and events in the past has been questioned by Avraham (2010) and is frowned upon by those who believe that the use of imagination has little value in the history classroom (Davis, Yeager, \& Foster, 2001). More significantly, they argue that as teenagers, learners have limited life experience and will therefore struggle to understand the complexity of contrived scenarios, while some researchers contend that it is almost impossible for learners to fully identify with victims of the extreme trauma of the Holocaust (Short \& Reed, 2004). It has therefore been recommended that role-play in Holocaust education should be avoided (Short \& Reed, 2004; Silbert \& Wray, 2004; Totten \& Riley, 2005). Moreover, there is a question as to whether empathy can really play the powerful role that Holocaust education has assigned to it and whether encouraging empathy in learners will result in their showing greater compassion and understanding for all racial, religious or other groups beyond the classroom. Can they, for instance, empathise with social or cultural groups that are very different from their own (Fay, 1996) or embrace values other than those with which they were raised (Du Preez \& Roux, 2010)? Taking these difficulties into account, Harris et al., (2004) caution that empathy should not be overplayed. 


\section{Methodology and methods}

Florence's personal story was originally told as part of a larger research project, the framework of which was an interpretive paradigm that fell within the ontological and epistemological boundaries of narrative inquiry. Narrative inquiry proposes that through story, human beings come to understand and therefore give meaning to their lives, that is, we use storytelling to construct and define our reality (Lai, 2010). As Polkinghorne (1988:107) explained, "people conceive of themselves in terms of stories" and these stories are structured to reflect the way their life has proceeded, thereby creating a coherent and basic theme that continues as they live out their lives. Personal stories are the foundation of our understanding of the world, providing the means to convert our knowing and experience into telling and in turn, telling gives meaning and substance to them (Kramp, 2004). Through our personal stories, we make sense of and explain the events of our lives, our feelings and thoughts, both to ourselves and to others. In the process of constructing a personal story, the storyteller draws not only the usual elements of plot, characters and a climactic ending, but also on his or her emotional knowledge. Emotions are written into the story. Thus, personal stories inevitably have an emotional dimension and the central themes of teaching are often moral and philosophical, having more to do with feelings, aims, aspirations, and personal meaning than with teaching methods or curriculum structures that exist outside of history teachers' personal experiences or biographies (Carter, 1993).

The narrative inquiry methodology used to analyse Florence's story was based on Riessman's five levels of representation for a narrative analysis (Riessman, 2000, 2005) - attending, telling, transcribing, analysing and reading. The research began with attending to the framing of the inquiry by developing the conceptual framework, defining the sampling and interviewing methods and identifying the participants. Narrative one-onone interviews were the basis of the data collection. The telling of the story followed when I interviewed Florence. Using narrative interview methodology (Wengraf, 2001), I posed a single question, then allowed her to respond for as long as she wished. As the narrative inquirer, my role was to attend to the content of her story, but also to why and how she told it as she did. I paid close attention to her descriptions of her personal experiences teaching the Holocaust with the aim of discovering if and how her personal story shaped her Holocaust pedagogy and philosophy (Clandinin, 2006; Riessman \& Speedy, 2007). 
Analysis was the next step with the first level of the narrative analysis being the transcription of the interview, followed by the second, the restorying of Florence's personal story in the style of a blog. Blogs are most commonly informal, relatively short pieces of writing, written in a conversational style that prompts responses from readers. This suited my perspective of Florence whose persona was chatty but also somewhat intense and this was able to be portrayed in a free-form blog. Topics covered included Florence's love of people and humanity, as well as explorations of various educational and emotive concepts as she navigated Holocaust themes. By treating Florence as a blogger, I was able to showcase these different topics thematically. A shortened, more conventional narrative version of Florence's personal story, with a beginning, middle and end, with a climax and portraying various characters is told below. The third level of the analysis was a thematic analysis of Florence's restoried story. With the analysis complete and the findings and conclusions drawn, the narrative inquiry was passed on to the reader for the final level of representation, reading.

\section{Florence's personal story}

Florence was a young Coloured South African woman who grew up in a lower middle-class suburb in Durban, South Africa and went on to become a history teacher, not only in the same suburb in which she grew up but in the very same school. As a child, she experienced a happy, stable home environment, living with her parents and six siblings in a house across the road from the school she attended. After she matriculated, she attended a local university, graduating as a history teacher and then returning to teach at her alma mater.

Despite the seeming simplicity of Florence's story, which was not filled with dramatic tales of intimidation, flight, or fear, as some history teachers' stories are, being racially classified as Coloured imposed its own burdens, as discussed earlier. Being racially classified forced people into little boxes, and Florence and her family were sandwiched between the polarising opposites of Black and White with little option but to forge their own identity. Florence and her family chose not to become activists or enter the contested political arena, but to build the best life they could under the circumstances while remaining within the confines of the sociopolitical restrictions imposed on them. 
At the time of South Africa's first democratic election in 1994, Florence was six years old and, post-apartheid, she and her family continued to do what they had always done; fly under the radar. They were, overall, apolitical and the closest Florence's father came to political involvement, was his membership of the African National Congress (ANC), even though he was sceptical of their motives, being convinced that the ANC wanted to relocate all Coloureds to the Western Cape, a move he vehemently opposed. Mostly though, he was a patriot who revelled in his love of everything South African.

For Coloured people, education was one way to beat the system, to succeed and to mask the existential pain they experienced as victims of apartheid. Florence's father placed great emphasis on education as a means for Coloureds to better themselves and he urged all his children to get an education, telling them, “They can't take it away from you!" Her father's positivity and political and educational choices impacted on her outlook on life, and she too dodged politics, even as she lived through it. Furthermore, her thoughts and feelings reflected her place in what she described as a large, happy, diverse family. Her brother had married an Indian woman and she taught mainly Black learners, without exhibiting signs of inferiority or superiority. While Florence might have remained "stuck" in the classification imposed on her by feeling racially prejudiced or stereotyped, as others have done (Debut, 2019:np; Harvey, 2016, no page), she did not portray evidence of discrimination.

With education being a means to transcend apartheid and, being a product of her education-driven family, Florence also valued education highly, so forged her identity as a history teacher. The school at which she taught was comprised of predominantly Black and Coloured learners but for Florence, even that classification of people was anathema; besides, she felt that she had other differences with which to contend, such as language and cultural barriers. She wanted people, including her learners, to get beyond racial categories and prejudice and recognise each other's humanity. To this end, she called her learners "Smurfs," as they all wore blue uniforms, a moniker that they embraced wholeheartedly. She would also tell them, "Even though I'm Coloured and you're Black, when we talk to each other we are all people. First we are people before we are put into any categories". 


\section{Emotion, empathy, identity and Holocaust education}

Being a history teacher, Florence was required to teach the Holocaust as it appeared in the CAPS-History curriculum. As the literature has shown, the Holocaust is an emotive topic, and Holocaust education can generate various and sometimes unexpected, controversial and emotive issues. It also raises issues of identity and history teachers and learners are often prompted to examine who they are as South Africans, as members of a particular racial group, and as people. Memory and identity therefore play significant roles for history teachers, who were, and still are, products of apartheid.

\section{Emotion and visualisation}

In terms of her personality, Florence self-identified as a highly emotional person. In particular, when teaching, she felt deeply about the pain inflicted and experienced with regard to genocide, including the Holocaust. As a result, her first encounter with teaching it was anything but neutral or positive. Her own intense feelings were reflected in her methodology.

Certainly, the first time I taught [the Holocaust] to Grade 9s, I thought I needed to show them exactly what happened, and this was the way to do it! I showed them horrendous graphic images of emaciated people, piles of dead bodies, and bodies being loaded into crematoria and I said, "Well this is what happened, and you need to know it!" The children were shocked. Then I told them the most gruesome details of things like medical experiments and to be frank, I wanted to make it the scariest thing in the world for them (Gouws, 2018a: 170).

Florence was shocked, and she wanted her learners to feel the same. Being inexperienced and not giving too much thought at the time to the distress she might cause, she used shock and horror tactics (Gouws, 2018a), brutally exposing them to disturbing Holocaust images and narratives of torture. However, she soon realised that traumatising her learners was unproductive and educationally unsound, and she began exploring innovative methods to teach the historical events without distressing them, but simultaneously sensitising them to the suffering of other people.

Part of Florence's Holocaust teaching strategy arose out of her awareness that after a lunch break the learners were hot, energised, or laughing from a shared joke. She felt that this situation was not conducive to the gravity of the topic. Furthermore, she wanted to mitigate some of the responses of Grade 9 learners, like, "Yoh Miss! For real? It happened?" or displays 
of inappropriate laughter. She therefore wanted to sensitise the learners' emotions before they confronted the Holocaust. As she explained:

They must be able to think about those people and feel something. I don't like it when children laugh about something like the Holocaust ... You've got to get them to a point of empathy before you teach [it] (Gouws, 2018a:163).

In order to manage both her and the learners' historical understanding and emotions, Florence developed a unique methodology, based on her educational philosophy that empathy plus facts equals human knowledge (Gouws, 2018a) and grounded in her life experiences.

Having good insight into the context in which she taught, Florence's teaching of the Holocaust usually began with the use of images. She began at Grade 9 level showing a map of Germany, as she was aware that many of the learners were ignorant of simple facts such as the geographical location of Germany. Learning from her initial experience of teaching the Holocaust, the next step was the use of photographs; not the gruesome kind that she had used previously, but more oblique images like a pile of shoes. While she did not use role-play, she nonetheless drew on the learners' imaginations to envision situations that she believed had a degree of familiarity. Her words, intonation and inflection reflected her innate empathy for people. Using visualisation techniques, she instructed the learners to close their eyes before drawing a mental picture for them and thereby changing the atmosphere in the classroom. In constructing this visualisation, Florence followed the structure of stories generally, that is, with a beginning, middle and end, and with a climax that led to a moral conclusion. She pitched it within the range of 16-year-old learners' understanding and life experience by describing a young person their own age sitting alone on a floor in a room full of strangers. The situation then evolved into a mystery tale. She described one visualisation as follows (Gouws, 2018a:170):

I speak in a very quiet voice, almost like a meditation, and say:

Picture yourself ... inside a room ... stacked with many, many people. You are seated in a little corner. Your knees are against your chest. And all you're doing is wondering, when is it your turn? But your turn for what, because you don't know what you're doing there.

And then suddenly ... the door opens ... They call your number ... you look down on your arm and you see it's your number. And then you've got to pick yourself up. You don't know where you're going. Maybe you were promised that you're going to get something good and then you take a step forward, 
but you see everybody around you looks frightened. They look scared. But you're not scared because your number is called.

And you start walking ... and as you walk toward the doorway and you see the light, you go into that light. You continue walking. Everything around you is quiet. You're by yourself all of a sudden. And then suddenly, just when you think you're about to be happy, you see the bad guys. And they start to beat you. They start to curse you. They say bad words to you. And push you around. You fall. And at that moment ...

Open your eyes.

While this meditation/visualisation might be construed by some as manipulative, or even in some way, dangerous, Florence's telling of the mini story is as it is. This is the technique she adopted to alter the atmosphere in the classroom and tap into her learners' feelings. There was no attempt by any of the other history teachers in the study to even try to make their learners more receptive to what they were about to be taught.

Florence's meditation was clearly a construction and not historically convincing. Almost naïvely, she spoke about the protagonist of her visualisation feeling "happy", going "into the light" and possibly achieving a "good" outcome" at a time when good outcomes were few and far between and generally unlikely. Nor was the mini story based on documented Jewish experience. In this respect, it might have misled the learners to believe that this was how things happened, but as with the use of visualisation in all educational situations, Florence's mini story could be interpreted in various ways. Her use of imagination was, therefore, not without flaw, but her intention was not to replicate authentic fact. It was an attempt to tap into her learners' feelings, quieten their emotions and pique their curiosity enough to enable the class to be led through a thoughtful, respectful discussion about what occurred during the Holocaust. Certainly, some of the learners might have found this activity uncomfortable or stressful if it triggered personal suffering, but it should be borne in mind that the purpose of the meditation was not historical, but emotional and she sought to place the learners in an emotional state to enable them to empathise with the victims. The visualisation was predicated on both an intellectual and emotional level, prodding the learners to go beyond cold rationalisation to a point of feeling and empathy. She used this technique because in her experience, she had not found that showing the learners sad photographs or telling them the facts of the history were enough to trigger enough deep emotion and thus empathy. Using meditations or 
visualisations might not be pedagogically sound in terms of Holocaust education, but for Florence it achieved the desired effect.

\section{The impact of personal stories on emotion}

Florence's pedagogy arose out of her observations and insight into both her own experiences and those of other teachers, reflecting narrative inquiry epistemology. For instance, when observing a colleague ridicule a stereotyped image of a Jewish man's nose in a cartoon, she realised that while his method had led to raucous laughter, the topic had lost its gravity and the picture had lost its meaning (Gouws, 2018a). She had also concluded that dryly relating facts and figures left the learners emotionless, both in and beyond the classroom, and believed that this lack of emotion would be reflected in their thinking and writing, leaving them unable to empathise with Holocaust victims.

By ascribing meaning and structure to her personal experiences (Josselson, 2007), she drew both historical and emotional connections to the Holocaust, thereby demonstrating the efficacy of history teachers' stories, personal experiences and emotions to make sense of baffling, challenging or difficult material. In this respect, teachers' personal stories shape and inform their practice (Bell, 2002) and what they teach is framed within the context of their life histories.

As Florence grew both personally and professionally, she gained greater insight into the impact of emotion on her Holocaust education pedagogy. She herself shifted from being over-emotional and reactive, to embracing a gentler, more considered approach. She also became aware of the transference of feelings. Florence discovered early in her teaching career, by chance, that she could transmit her feelings to her learners who, in turn, felt the same as she did about various things (Härtel \& Page, 2009). She commented on the first time she experienced this phenomenon:

When I first taught about the genocide in Rwanda and [atrocities in] Burundi during my fourth year at university, I was doing a presentation and I cried in front of the class. I felt so silly but became aware that the rest of the class was also starting to feel what I was feeling. And the same thing happens with the Holocaust (Gouws, 2018a:162).

Teachers' and students' emotions are closely related, and teaching is more than simply instructional, with teachers also having the power to influence their learners' emotions (Becker et al., 2014). Research has shown that emotions can be transmitted directly or indirectly from 
the emotions of one person to another, or to a group of people (Härtel \& Page, 2009). With this in mind and being aware of the impact of the material on her learners' emotions, Florence was careful not to allow the learners' emotions to veer to extremes, insisting that she did not want her learners "sobbing and crying" in the classroom when they learnt about the Holocaust (Gouws, 2018a:172). For this reason, Florence tried to carefully manage her learners' emotions and to use "soft" materials when teaching the Holocaust, rather than confronting, shocking images, explanations, photographs or documentaries.

For Florence, the teacher-learner relationship was one of the keys to effective teaching and learning about the Holocaust, and the cross-pollination of teacher-learner emotions was reflected in the excellent relationship that existed between her and her learners. In this context, transference of emotion played an important role in her Holocaust teaching. It was important to Florence who believed that if learners liked their teachers, they were likely to be more fully engaged in the lesson. To enhance this relationship and to connect with the learners on an emotional level, she chose to expose her feelings, being unafraid to reveal her vulnerability, thereby creating a space for learners to understand and accept their own feelings. She ensured that her learners knew where she stood on any given topic, be it controversial or not, and then used her emotions to nudge her learners to feel the same.

\section{Personalisation in Holocaust education}

To negotiate a path though the emotional minefield of the Holocaust, many history teachers teaching the Holocaust employ empathy to encourage learners to consider the thoughts and feelings of victims, perpetrators and bystanders and to better understand how and why the Holocaust happened. This is done with the use of photographs, personal stories of survivors, books like The Diary of Anne Frank and films such as Schindler's List. Using these media, learners are encouraged to draw inferences about how others might feel given certain information, even though this information is not necessarily based on fact or knowledge but on their own "personal experiences, social relations, and everyday life" (Morgan, 2015:374). Empathy therefore shifts the learners' focus from themselves to others. However, this assessment is based not only on a direct comparison with their own feelings, but also with imagined feelings, which are generated by assessing others' cognitive and affective states (Harris et al., 2004). In this 
respect, empathy draws on personal stories. Florence embraced empathy as the key to unlocking the learners' understanding of the Holocaust by grounding her Holocaust education understanding on her own lived experiences and placing people, and not names and dates, at the core of her educational philosophy and methodology. But there is a question in the literature whether empathy can really play the powerful role in Holocaust education that has been assigned to it. Questions arise whether inculcating empathy in learners will result in them showing greater compassion and understanding for all racial, religious or other groups?

One way for history teachers to deal with these questions is to shift the attention from the big story of the Holocaust to the small stories of individuals through personalisation. Personalisation shines a spotlight on the complexity of a single person or a small group of people's lived experiences and in doing so, detracts from the difficulty of imagining a devastatingly large number of victims. Coming to grips with six million individuals can be overwhelming. One attempt to capture the enormity of the death of six million Jews was initiated in a project in which learners collected one paper clip for each Jewish victim; a project that ultimately resulted in the creation of a children's memorial (Schroeder \& SchroederHildebrand, 2014). It should be borne in mind, however, that whilst employing the concept of a paper clip to represent a person might be a creative attempt to overcome the difficulty of conceptualising six million dead people, pedagogically it is problematic. Using inanimate objects to personalize people's lives, omits to address the complexity and divergence of their experiences. Ultimately, paper clips cannot document the thoughts and feelings of people. In contrast, books such as Elie Wiesel's Night can provide precise details of what a person experienced during the Holocaust, thereby providing greater insight into and understanding of the complexity of uncommon, traumatic and dehumanising events of the Holocaust (Wiesel, 2008).

Recognising the effectiveness of personalisation, schools and Holocaust museums around the world use Holocaust survivors themselves, where possible, to tell their stories to learners, as their testimony is powerful and educational. In South Africa, however, Holocaust survivors seldom visit schools and the number of survivors is ever dwindling, due to their advancing years. Holocaust museums also generally educate visitors using video material of the first-hand testimony of Holocaust survivors (Pettigrew et al., 2009; Smith, 2019). In the classroom, without access to the 
physical presence of survivors, bystanders, rescuers and even perpetrators, to tell their stories, personalisation is achieved through the medium of films, books, or videos and in the future, possibly even holograms (Reynolds, 2019). Films like The Boy in the Striped Pyjamas are often used to initiate emotional connections between learners and the Holocaust narrative through empathy for the characters. However, this film is a very controversial choice for Holocaust educators as it has been criticised for being a work of fiction that uses sentimentality to evoke empathy (Gilbert, 2010) as well as containing historical and geographical inaccuracies. Schindler's List is another oft-used film about Jewish experience during the Holocaust and has sometimes even been used to take the place of Holocaust lessons (Gouws, 2018a). But caution has been advised in the use of media where there is any suggestion of emotional exploitation.

Hearing the personal stories of those who lived through the Holocaust is a powerful, emotional, empathy-generating experience with their stories of survival, escape, brutality, fear and violence connecting them emotionally to those who hear them. Work is therefore being undertaken to preserve Holocaust memory through a ground-breaking technological project at the University of South California under the direction of its Executive Director, Stephen D. Smith. Called Dimensions in Technology, interactive biographies are being constructed using 3D holograms and artificial intelligence that will enable people to interact and converse with pre-recorded video images of Holocaust survivors and other witnesses to genocide (USC Shoah Foundation, 2019). As Stephen D. Smith explained, "Everyone thinks the Shoah Foundation is about archiving the past but it's about understanding empathy and using testimony to shine a light." (Popescu, 2018:np). Regrettably, artificial intelligence will most likely not be usable in South African classrooms for quite some time, particularly in rural schools where today even the internet is a luxury. Instead, transference of knowledge about the Holocaust generally takes place through the history teacher, who is present with her learners. Currently, there might be a computer, linked to the internet, a chalk board, smart board in exceptional circumstances, and a textbook. Furthermore, in the South African context, education about the Holocaust is fact-based under the CAPS guidelines - it is not about memorial, Jewish memory or even Holocaust memory, but about the events that occurred between 1933 and 1945 under Nazi Germany. Besides the difficulty of using first-hand survivor testimony, the focus in the CAPS curriculum is, in fact, more content driven, rather than 
being social-based and there is no inclusion of Jewish memorials or the fate of survivors.

Beyond the personal stories of those who lived during the Holocaust, other personal stories also filter into the classroom, namely, the personal stories of the history teachers who teach it. History teachers cannot be separated from their personal stories and they integrate these stories into their content knowledge, mixing them with the parallel narrative of the Holocaust. For instance, one history teacher in a rural high school explained that he needed to draw on his knowledge of apartheid, which what was known to him, to explain the unknown, which was the Holocaust (Gouws, 2018a). For almost all South African history teachers, the Holocaust is not a part of their family stories, cultures, or history, as it is for many history teachers in Europe. By drawing parallels with their own stories, personalisation can be achieved by the history teachers by using concrete examples of similar or parallel, personal events instead of using abstractions and generalizations which have little bearing on learners' lives. This adds to the authenticity of the learners' understanding. The history teachers share their experiences through the device of storytelling, thereby building bridges of understanding between themselves and the learners (Abrahamson, 2011; Maguire, 1998). However, unlike Florence who told her personal story with few filters, other history teachers do not necessarily tell their stories overtly. In fact, some history teachers' personal stories are hidden, suppressed, or simply veiled, although the story itself still informs what is taught (Gouws, 2018a).

Despite the positive aspects of the use of empathy in Holocaust teaching and learning, there are nevertheless also barriers and exceptions. Apathy or indifference on the part of history teachers might stand in the way of successfully teaching the Holocaust, or as discussed earlier, history teachers might be contending with their own traumatic histories and feel less than motivated to deal with a traumatic history like the Holocaust. For others, getting learners with little contextual understanding to understand complex dilemmas, fears or pain, might be challenging and learners' understanding of the past might, in fact, be very different from their experience of the present (Harris et al., 2004). South African learners live in a present that has little or no reference to the terror and trauma of WWII. They are millennials, who are deeply entrenched in a digital world dominated by social media. This is an internet-based world that is far removed from communication methods during WWII such as newspapers, 
radio, telegraph, analogue telephones, and "snail mail". In this digitised space, it might be difficult for learners to truly understand the impact in the 1930s and 1940s of the absence of cell phones, internet, instant messaging, and the ability to instantly record and disseminate information, either verbally or photographically. Also, due to the shortage of time or the lack of interest or knowledge by the history teacher, this relevant contextual knowledge might be missing (Harris et al., 2004).

\section{Approaches to and implications for teaching the Holocaust}

Despite the emotional impact of teaching the Holocaust, in general, history teachers search for ways to help their learners gain insight into the complexities of the Holocaust - what it is and how and why it happened. At one end of the spectrum, some adopt a cool, professional, objective approach and just teach "the facts" while at the opposite end, a more lessons-infused, socially focused Holocaust history is taught, with the history teachers focusing on how the past can inform and transform the present. These dichotomous views are certainly not mutually exclusive, and most history teachers find themselves vacillating between the two. Furthermore, threading its way through both approaches, are the personal stories that the history teachers tell to inject emotion and connection into their Holocaust lessons. These stories reflect the identity of the history teachers.

\section{Barriers to empathy}

It is tempting to believe that all people will empathise with the struggles or suffering of others. But this is not so. Despite the widespread praise and use of empathy in Holocaust education, the identity of the history teachers or their learners, can provide a barrier to empathy. Due to family or social backgrounds, negative attitudes might filter into Holocaust lessons. For instance, learners who arrive in class with pre-formed ideas of identity in which their historical perspective is one of Us vs. Them (Cikara, Bruneau, \& Saxe, 2011) might find it difficult to empathise with a Them group. In one study, for example, it was found that amongst the explanations for current antisemitism among Muslims and Arabs, empathy for Holocaust victims was viewed as "a source of frustration" and "a concession to "the Jews" (Jikeli, 2013:6). In terms of the South African context, examples of both antisemitism and Islamophobia can be found, lending credence to the idea of learners arriving with pre-conceived ideas of the "other". 
With contested dichotomies of Black vs. White, Jews vs. Nazis, powerful vs. disempowered being littered across the Holocaust education landscape, learners might well bring pre-conceived ideas about various groups to lessons about the Holocaust. For example, if learners' moral obligations are divided from the outset and the image of "the other" is objectified, then they might indeed have low levels of empathy for the "out" group (Gobodo-Madikizela, 2002:23). In this case, asking learners to choose the right thing to do, such as standing up for justice or human rights, might have a different meaning from that intended by the history teacher. Other obstructions to empathy might lie in the Holocaust being viewed through the lens of colonialism (Freedman, 2010), which is derided in South African consciousness (Le Grange, 2016). Yet another is asking learners to come to grips with the vast number of Jewish victims. The sheer magnitude of the Holocaust and the vast number of victims could also overwhelm learners, so that instead of contemplating the fate of a few individuals, they must grapple with the vastness of six million individuals. This could be alienating for both teachers and learners, who could start to conceptualise the Holocaust in terms of unitary concepts, speaking of the six million, rather than six million individuals, thereby depersonalising them. In fact, the use of empathy troubles the notion that as human beings, we will easily identify with the suffering of others and empathise with them, as this is not necessarily so.

As we have seen, emotion in the classroom when the Holocaust is being taught is unavoidable, but employing it as part of a methodology, as Florence did when generating empathy in her learners, can be a doubleedged sword. History teachers do not intentionally set out to upset their learners and Florence was no exception, but their chosen methodology might do just that when they use emotion as a didactic avenue. It is therefore necessary to strike a balance between empathy and pathos, which can be a delicate task, and while an empathic response to the Holocaust might be the goal of history teachers, achieving empathy might not always be achievable.

\section{Identity and Colouredness}

Teachers' identities are integrated into their practice (Jansen, 2008; Seetal, 2006). This includes their personal knowledge, who they are, where they came from, the context in which they grew up (Clandinin, 1985) and their practical knowledge, which is informed by their personal experiences, 
backgrounds and personal characteristics (Clandinin \& Connelly, 1988; Watson, 2006). This means that they shape their lessons according to how they position themselves (Geschier, 2010).

Generally, history teachers are committed to their professionalism (Rizvi \& Elliot, 2005; Swann, McIntyre, Pell, Hargreaves, \& Cunningham, 2010) and almost all of the history teachers in my $\mathrm{PhD}$ study taught the Holocaust to the best of their ability irrespective of their personal backgrounds. However, the Holocaust stirred up deep emotion and many felt overwhelmed by sadness but tried not to let these feelings overwhelm them. They looked both inwards, trying to identify their vulnerable spots, and outwards, to their families and communities, or sometimes searching for political or educational answers.

For Florence, teaching the Holocaust meant being sad. Despite recognising that she was an emotional person who cried easily (Gouws, 2018a), this did not take away the sadness that descended on her when she taught the Holocaust. Other history teachers have different emotional responses. To understand why the Holocaust affected the history teachers so deeply meant digging into the most hidden parts of their personal stories and exposing their identities. For Florence, this was her "Colouredness," through which she brought intrinsic knowledge to her Holocaust teaching. Beneath her determination to succeed lay the hurts and indignities of apartheid, hidden and waiting to find expression, and those feelings emerged when she was confronted with the horrors of the Holocaust, genocide, and, crucially, "the horrific way in which people treat others when they think that they are different from them" (Gouws, 2018). This was significant because Florence knew what it was like to be considered "different" - being neither white nor black in a polarised country. What many Coloured people did, and still do, was to mask their pain, feeling that they were too Black before 1994 and too White thereafter (Debut, 2019:np).

To say that all Coloured history teachers react in the same way to teaching the Holocaust would be patently wrong, because Coloured identity is very complex and contested in South Africa, where certain attitudes and behaviours have been retained for reasons of redress, such as clinging to racial inequalities. But their personal stories expose how they teach the Holocaust. This diversity of experience within each group occurs because South Africans have no national identity and until government decrees otherwise, post-apartheid categorisation remains. Within this system, 
individuals need to self-identify and self-actualise. In the case of Florence, she self-identified in her personal story as Coloured, as discussed in the footnote on page one. As part of a marginalised community Florence's family had endured trials and tribulations but had chosen to rise above them. Her parents taught their children how to behave, how to move beyond the past, and to focus on education. Being supported by a loving family, Florence submerged her troubled feelings beneath a veneer of professionalism, enthusiasm, and stoicism, adopting the same choices that had been made by the family to survive the system. Instead of protest, they had negotiated their lives as best they could and navigated the system. Florence was able to continue this practice, until the cracks appeared in the smooth façade that she presented to the world when she came face to face with how badly Jews in the Holocaust were treated under racial laws that mirrored her own experience. When she began researching the Holocaust, she discovered that it reflected deep elements of her own past. She was challenged to examine her Coloured identity and reflect on how she too had become a marginalised person in her own country. In the textbook she was confronted with images and narratives of gross human rights abuses that shocked her, yet these were images with which she could empathise and to which she could relate, as she understood them on a profoundly personal level. Her classroom persona, of dedicated history teacher, girlfriend, daughter, and enthusiastic liver of life, was prised open leaving her with sadness. The tethering of Florence's past to her present and the teaching of the Holocaust is well-documented in post-apartheid South African research. It has been found that history teachers cannot separate themselves from their apartheid baggage when they teach about the Holocaust (Nates, 2011; Tibbitts, 2006; Weldon, 2005; 2008). This was reflected whenever Florence taught pseudo-scientific racism, which, she said, always sparked "an emotional moment" (Gouws, 2018a:165), as it was a response to the violation of the human rights of her Coloured community under apartheid. It was therefore evident, that while coping with the emotional complexity of the Holocaust, history teachers overlaid the issues at hand with layers of their own painful experiences, memories and emotions. 


\section{Conclusion}

In the history classroom in South Africa, memory of apartheid and memory of the Holocaust have an innate political agenda, driven by government educational policy and supported by Holocaust centres. For instance, the Durban Holocaust and Genocide Centre, provides workshops for schools in support of the curriculum and has as its agenda, "highlighting the consequences and dangers of indifference, apathy and silence [and] strives towards improving the quality of human life in our society" (Durban Holocaust and Genocide Centre, 2019). However, the curriculum is once again in flux and the presence of the Holocaust in the curriculum is once again being debated with a shift in focus to Africanisation of the curriculum and a move away from the current European dominance of school history.

Holocaust education in South Africa today focuses on South African history by highlighting our recent past with its human rights abuses, and develops values and agency to create an integrated, cohesive society. Ultimately, the stories of the history teachers are stories of South African history, South African educational history and South Africans' personal stories. Florence therefore taught the Holocaust as it was intended, as a parallel to apartheid history and a segment of WWII history. Her teaching of the Holocaust was far from perfect, but she was teaching an unfamiliar history to the best of her ability, with a focus on the development and well-being of her learners. She used visualisations to sensitise her learners and help them grasp the enormity of the genocide of six million Jews and at the same time taught them to empathise with the lived experiences of Holocaust victims. She did this by revealing her identity and telling her story.

Teachers are their stories (Bruner, 1987; Schama, 2013) and they are also products of their societies (Slater, 1995). Hence, teaching and learning about the Holocaust is shaped by the history teachers' relationships, family, and community. In South Africa, racial discrimination and apartheid dominate the discourse around teaching trauma histories such as the Holocaust and because history teachers cannot separate themselves from what they teach (Nates, 2011), their personal stories become integrated into it, be it consciously or subconsciously. In addition, history teachers experience an emotional connection when teaching about the Holocaust. Those who experience the pain, trauma and humiliation of apartheid draw parallels between their personal experiences and those of Holocaust victims. Some conflate their stories, histories and memories of apartheid, providing 
emotional accounts of their or their family's experiences, while others avoid emotion as much as possible, giving a cool, linear account of what happened during the Holocaust in support of the CAPS-History curriculum agenda. Yet others relate their personal stories to what happened to their families in WWII or simply respond emotionally to teaching about the horrors of the Holocaust, using their personal stories to highlight human rights abuses and encouraging their learners to be active in the fight against prejudice and further genocides.

In Holocaust education, familial stories of parallel occurrences link past and present, but emotion in those stories is the glue that binds the history teachers' personal stories to the Holocaust narrative. However, it should be remembered that personal stories are not always positive or simple. They are convoluted, complex and are filled with both positive and negative emotions. Moreover, whilst being cognisant of the fact that one personal story cannot be generalised to all teachers who teach the Holocaust, a narrative inquiry into Florence's personal story was a means of discovering the place of the personal story in Holocaust education and revealed how she taught the Holocaust. Her pedagogy was underpinned by the dictates of the CAPS-History curriculum, but she developed her own methods as part of her life philosophy, which was exemplified by her oft-used mantra, "Listen, can we be people? Why must we be anything but people?" This led her to develop an empathy-based methodology. But, perhaps more than any other factor, Florence's identity as a Coloured South African shaped her teaching of the Holocaust.

What Florence taught and how she taught it might seem questionable to some, but she was not teaching the Holocaust in the rarefied atmosphere of a Holocaust museum, nor for the purposes of pure Holocaust education, but in a school environment as part of her everyday teaching, teaching the topic as best she could in a limited time frame. Her story reveals how the Holocaust is taught in schools where the history teacher is not a Holocaust specialist and is unaware of the hype surrounding Holocaust education at an international level. She is simply trying to make the topic usable for learners who live in a world far removed from the 1930s technological world of trains and European antisemitism and where they might not be able to comprehend that a man such as Hitler or a group like the Nazis even existed. This was evident when a group of learners visited the Durban Holocaust and Genocide Centre recently, and then posed outside the centre doing the Nazi salute and grinning widely, completely unaware of the 
inappropriateness of their actions. This is the legacy of using the Holocaust for nation-building, human rights and other purposes. In a nutshell, this is how the Holocaust is being taught in schools today. Seventy years on and in a new context, this is essentially the new frontier of Holocaust education, where the history is removed from pure Holocaust history, but needs to be made useful in a new context to people who are most likely completely unaware of it. For many people around the world, the death of six million Jews is shocking but does not touch their lives. Yet in a South African classroom, the story of the Holocaust touched a young Coloured history teacher because it touched her personal story.

\section{References}

Abrahamson, CE 2011. Methodologies for motivating student learning through personal connections. Paper presented at the Forum on Public Policy Online.

Avraham, D 2010. The problem with using historical parallels as a method in Holocaust and genocide teaching. Intercultural Education, 21(sup1):S33-S40. DOI:10.1080/14675981003732225.

Becker, ES, Goetz, T, Morger, V, \& Ranellucci, J 2014. The importance of teachers' emotions and instructional behavior for their students' emotions-An experience sampling analysis. Teaching and Teacher Education, 43:15-26.

Bell, JS 2002. Narrative Inquiry: More than just telling stories. TESOL Quarterly, 36(2): 207-213. DOI:10.2307/3588331.

Bromley, P, \& Russell, SG 2010. The Holocaust as history and human rights: A crossnational analysis of Holocaust education in social science textbooks, 1970 2008. PROSPECTS, 40(1):153-173.

Bruner, J 1987. Life as narrative. Social Research, 54(1):11-32. DOI:10.2307/40970444.

Carter, K 1993. The place of story in the study of teaching and teacher education. Educational Researcher, 22(1):5-18.

Chikoko, V, Gilmour, JD, Harber, C, \& Serf, J 2011. Teaching controversial issues and teacher education in England and South Africa. Journal of Education for Teaching, 37(1):5-19. DOI:10.1080/02607476.2011.538268.

Cikara, M, Bruneau, EG, \& Saxe, RR 2011. Us and them: Intergroup failures of empathy. Current Directions in Psychological Science, 20(3):149-153. 
Clandinin, D J 2006. Narrative inquiry: A methodology for studying lived experience. Research Studies in Music Education, 27(1):44-54. DOI:10.1177/132110 3X060270010301.

Clandinin, DJ, \& Connelly, FM 1988. Studying teachers' knowledge of classrooms: Collaborative research, ethics, and the negotiation of narrative. The Journal of Educational Thought (JET)/Revue de la Pensée Educative, 22(2A):269-282.

Corfield, PJ 2008. All people are living histories - which is why History matters. Making History.

Cushman, L 2016. Assessment in the teaching of Holocaust history and theories of race. Yesterday and Today, (16):100-116.

Davis, OL, Yeager, EA, \& Foster, SJ (2001). Historical empathy and perspective taking in the social studies. Rowman \& Littlefield.

Debut, B 2019. Why some in SA's Coloured community are nostalgic for apartheid. Politics. Available at https://www.iol.co.za/news/politics/why-some-in-sascoloured-community-are-nostalgic-for-apartheid-21976139. Accessed on 30 June 2019.

Department of Basic Education 2011a. National Curriculum Statement - Curriculum and Assessment Policy Statement Grades 10-12 History. Pretoria: Government Printing Works Available at http://www.education.gov.za/Portals/0/ CD/National\%20Curriculum\%20Statements\%20and\%20Vocational/ CAPS \%20FET\%20\%20HISTORY\%20GR\%2010-12\%20\%20WeB. pdf?ver=2015-01-27-154219-397. Accessed on 3 July 2019.

Department of Basic Education 2011b. National Curriculum Statement - Curriculum and Assessment Policy Statement Social Sciences Grades 7-9. Pretoria: Government Printing Works. Available at http://www.education.gov. za/Portals/0/CD/National $\% 20$ Curriculum $\% 20$ Statements $\% 20$ and $\% 20$ Vocational/CAPS \%20SP\%20\%20SOCIAL\%20SCIENCE\%20GR\%20 7-9\%20\%20.pdf?ver=2015-01-27-160206-107. Accessed on 5July 2019.

DepartmentofBasicEducation.(2018). ReportoftheHistoryMinisterialTaskTeam.Pretoria: Department of Basic Education Retrieved from https:/www.education.gov. za/Portals/0/Documents/Reports/Report\%20of\%20the\%20History\%20 Ministerial\%20Task\%20Team.pdf?ver=2018-06-07-154241-410. Accessed on 5 July 2019.

Department of Basic Education 2018. Report of the History Ministerial Task Team. Pretoria: Department of Basic Education. 
Department of Education 2002. Revised National Curriculum Statement Grades R-9 (Schools) Social Sciences. Pretoria. Available at https://www.education. gov.za/Portals/0/CD/GET/doc/social.pdf?ver=2006-11-21-100207-000. Accessed on 5 July 2019.

Du Preez, P \& Roux, C 2010. Human rights values or cultural values? Pursuing values to maintain positive discipline in multicultural schools. South African Journal of Education, 30(1).

Durban Holocaust and Genocide Centre 2019. About us. Durban Holocaust and Genocide Centre. Available at http://dbnholocaust.co.za/about-us/. Accessed on 5 July 2019.

Fay, B 1996. Contemporary philosophy of Social Science: A multicultural approach: Wiley-Blackwell.

Freedman, R 2010. Creating a voice for human rights: The work of the South African Holocaust Foundation in Holocaust education in South Africa. Paper presented at the Federation of International Human Rights Museums Conference 2010, International Slavery Museum, Liverppool, UK. Available at http://www.fihrm.org/conference/conference2010.html. Accessed on 5 July 2019.

Freedman, R 2015. Engaging with Holocaust education in Post-Apartheid South Africa. Occasional paper series No. 10. Available at https://www.fihrm.org/ wp-content/uploads/2017/07/Richard-Freedman-Aegis-and-role-of-firstHolocaust-Centre-in-Africa.pdf. Accessed on 5 July 2019.

Gaines, RE, Osman, DJ, Maddocks, DL, Warner, JR, Freeman, JL \& Schallert, DL 2019. Teachers' emotional experiences in professional development: Where they come from and what they can mean. Teaching and Teacher Education: An International Journal of Research and Studies, 77(1):53-65.

Geschier, SM 2010. 'South Africans did, Miss, we, we fought for our freedom': Pedagogy and the potential of primary narratives in a history classroom. Education as Change, 14(1):47-60.

Gilbert, R 2010. Grasping the unimaginable: Recent Holocaust novels for children by Morris Gleitzman and John Boyne. Children's literature in education, 41(4):355-366.

Gobodo-Madikizela, P 2002. Remorse, forgiveness, and rehumanization: Stories from South Africa. Journal of Humanistic Psychology, 42(1):7-32. DOI:10.1177/0022167802421002 
Gouws, B 2018a. Investigating Holocaust education through the personal stories of history teachers. (PhD Full dissertation). University of KwaZulu-Natal, Durban.

Gouws, B 2018b. Investigating Holocaust education through the personal stories of history teachers. (PhD Full Dissertation). University of KwaZulu-Natal, Durban.

Hargreaves, A 1998. The emotional practice of teaching. Teaching and Teacher Education, 14(8):835-854.

Harris, R, Foreman-Peck, L \& Northants, UK 2004. 'Stepping into other peoples' shoes': Teaching and assessing empathy in the secondary history curriculum. International Journal of Historical Learning, Teaching and Research, 4(2):98-111.

Härtel, CEJ, \& Page, KM 2009. Discrete emotional crossover in the workplace: The role of affect intensity. Journal of Managerial Psychology, 24(3):237-253.

Harvey, E 2016. The rise of a new black racism in South Africa. Mail \& Guardian.

Jansen, JD 2008. Bearing Whiteness: A pedagogy of compassion in a time of troubles. Education as Change, 12(2):59-75. DOI:10.1080/16823200809487207

Jikeli, G 2013. Perceptions of the Holocaust among young Muslims in Berlin, Paris and London. In G Jikeli \& J Allouche-Benayoun (Eds.), Perceptions of the Holocaust in Europe and Muslim communities, 5:105-131. Dordrecht Heidelberg New York London: Springer.

Josselson, R 2007. The ethical attitude in narrative research: Principles and practicalities. In DJ Clandinin (Ed.), Handbook of Narrative Inquiry: Mapping a Methodology, 21:545.

Kelman, HG 1973. Violence without moral restraint: Reflections on the dehumanization of victims and victimizers. Journal of Social Issues, 29(4):25-61. DOI:10.1111/j.1540-4560.1973.tb00102.x

Kramp, MK 2004. Exploring life and experience through narrative inquiry. In Foundations for research: Methods of inquiry in education and the social sciences:103-121. Lawrence Erlbaum Associates, Inc.

Lai, CKY 2010. Narrative and narrative enquiry in health and social sciences. Nurse Researcher, 17(3):72-84. Available at http://search.ebscohost.com/login.asp $\mathrm{x}$ ?direct $=$ true $\& \mathrm{db}=\mathrm{a} 9 \mathrm{~h} \& \mathrm{AN}=50369048 \&$ site $=$ ehost-live. 
Le Grange, L 2016. Decolonising the university curriculum: Leading article. South African Journal of Higher Education, 30(2):1-12.

Lindquist, DH 2007. A necessary Holocaust pedagogy: Teaching the teachers. Issues in Teacher Education, 16(1):21-36. Available at https://files.eric.ed.gov/ fulltext/EJ796255.pdf. Accessed on 5 July 2019.

Maguire, J 1998. The power of personal storytelling: Spinning tales to connect with others. New York: JP Tarcher/Putnam.

McCully, A 2012. History teaching, conflict and the legacy of the past. Education, Citizenship and Social Justice, 7(2):145-159.

Moisan, S, Hirsch, S \& Audet, G 2015. Holocaust education in Quebec: Teachers' positioning and practices. McGill Journal of Education/Revue des sciences de l'éducation de McGill, 50(2-3):247-268.

Morgan, KE 2015. Learning empathy through school history textbooks? A case study. Rethinking History, 19(3):370-392. DOI:10.1080/13642529.2014.898815

Nates, T 2010. 'But, apartheid was also genocide ... What about our suffering?' Teaching the Holocaust in South Africa - opportunities and challenges. Intercultural Education, 21(1):S17-26.

Nates, T 2011. Holocaust Education in South Africa. Holocaust and the United Nations - Discussion Paper Series. Available at http://www.un.org/en/ holocaustremembrance/docs/paper12.shtml. Accessed on 5 July 2019.

Pettigrew, A, Foster, S, Howson, J, Salmons, P, Lenga, R-A \& Andrews, K 2009. Teaching about the Holocaust in English Secondary Schools. Available at London, United Kingdom: https://www.holocausteducation.org.uk/ wp-content/uploads/Final-Report-Master-Document-19-October-2009HIMONIDES_.pdf. Accessed 5 July 2019.

Pillay, S 2019. Being Coloured and Indian in South Africa after apartheid. Africa is a country. Available at https://africasacountry.com/2018/06/being-colouredand-indian-in-south-africa-after-apartheid. Accessed on 5 July 2019.

Polkinghorne, DE 1988. Narrative knowing and the human sciences. State University of New York Press.

Popescu, A 2018. Steven Spielberg on storytelling's power to fight hate. The New York Times. Available at https://www.nytimes.com/2018/12/18/arts/design/stevenspielberg-shoah-foundation-schindlers-list.html. Accessed on 5 July 2019. 
Reynolds, D P 2019. Holocaust memory in the digital age. Survivors' stories and new media practices. In Taylor \& Francis:438-440.

Riessmann, CK 2000. Analysis of personal narratives. Boston University. Retrieved from http://alumni.media.mit.edu/ brooks/storybiz/riessman.pdf. Accessed on 5 July 2019.

Riessman, CK 2005. Narrative analysis. Narrative, memory \& everyday life, 1-7. Available at http://eprints.hud.ac.uk/4920/. Accessed on 5 July 2019.

Riessman, CK \& Speedy, J 2007. Narrative Inquiry in the psychotherapy professions: A critical review. In DJ Clandinin (Ed.), Handbook of Narrative Inquiry: Mapping a Methodology. United States of America: Sage Publications, Inc.

Rizvi, M \& Elliot, B 2005. Teachers' perceptions of their professionalism in government primary schools in Karachi, Pakistan. Asia-Pacific Journal of Teacher Education, 33(1):35-52.

Schama, S 2013. The story of the Jews [DVD]: BBC.

Schroeder, PW \& Schroeder-Hildebrand, D 2014. Six million paper clips: The making of a children's Holocaust memorial. Minneapolis: Kar-Ben Publishing, Inc.

Seetal, S 2006. Reconceptualising history teachers' identities within the context of changing curriculum. Yesterday \& Today: 2006 (Special Edition), 26. Available at http://hdl.handle.net/10394/5646. Accessed on 5 July 2019.

Short, G \& Reed, CA 2004. Issues in Holocaust education. Ashgate Publishing Company.

Silbert, M \& Wray, D 2004. The Holocaust: Lessons for humanity-learners'interactive resource book. New Africa Books (Pty) Ltd \& The Cape Town Holocaust Centre.

Slater, J 1995. Teaching history in the new Europe. London: Council of Europe: Cassell: Continuum International Publishing Group Ltd.

Smith, SD 2019. New dimensions in survivor testimony. Durban.

Swann, M, McIntyre, D, Pell, T, Hargreaves, L, \& Cunningham, M 2010. Teachers' conceptions of teacher professionalism in England in 2003 and 2006. British Educational Research Journal, 36(4):549-571. DOI:10.1080/01411920903018083.

Tibbitts, F 2006. Learning from the past: Supporting teaching through the "Facing the past". History Project in South Africa. Prospects (Paris, France), 36(3):295317. DOI:10.1007/s11125-006-0013-4. 
Totten, S, \& Riley, KL 2005. Authentic pedagogy and the Holocaust: A critical review of state sponsored Holocaust curricula. Theory \& Research in Social Education, 33(1):120-141. DOI:10.1080/00933104.2005.10473274.

USC Shoah Foundation. (2019). Dimensions in Testimony. Research Initiatives.

Van Driel, B 2003. Some reflections on the connection between Holocaust education and intercultural education. Intercultural Education, 14(2):125-137. DOI:10.1080/14675980304572.

Wassermann, J 2011. Learning about controversial issues in school history: The experiences of learners in KwaZulu-Natal Schools. Journal of Natal and Zulu History, 29:131-157.

Wassermann, J \& Bentrovato, D 2018. Confronting controversial issues in History classrooms: An analysis of pre-service high school teachers' experiences in post-apartheid South Africa. Yesterday and Today, 72-90. Available at http://www.scielo.org. za/scielo.php?script=sci_arttext\&pid=S2223-03862018000200005\&nrm=iso. Accessed on 5 July 2019.

Waterson, RA 2009. The examination of pedagogical approaches to teaching controversial public issues: Explicitly the teaching of the Holocaust and comparative genocide. Social Studies Research and Practice, 4(2):24. Available at http:// www.socstrpr.org/files/Vol\%204/Issue\%202\%20-\%20Summer,\%202010/ Research/4.2.1.pdf. Accessed on 5 July 2019.

Watson, C 2006. Narratives of practice and the construction of identity in teaching. Teachers and Teaching, 12(5):509-526. DOI:10.1080/13540600600832213.

Weldon, G 2005. Thinking each other's history - can facing the past contribute to education for human rights and democracy. International Journal of Historical Learning, Teaching and Research, 5(1):61-70.

Weldon, G 2008. History education and the democratic nation in post-apartheid South Africa. Paper presented at the South African Society for History Teaching (SASHT).

Wengraf, T 2001. Qualitative research interviewing: Biographic narrative and semistructured methods: SAGE Publications Ltd.

Wiesel, E 2008. Night, 55. Penguin. 